\title{
Carbonation for cement mortar by using the sparging process of supercritical $\mathrm{CO}_{2}$
}

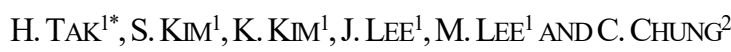

${ }^{1}$ Dept. of Earth Environmental Sciences, Pukyong National University,

South Korea (*correspondence: thg110627@gmail.com)

${ }^{2}$ Dept. of Architectural Engineering, Pukyong National University, South Korea

Recycled aggregate derived from construction waste increases the $\mathrm{pH}$ level of the water system due to the alkalinity of cement pastes attached on the surface of recycled aggregate. Therefore, for reusing in the field, the recycled aggregate should be treated with the available neutralization process so that it maintains below $\mathrm{pH} 9.8$ (the Korean tolerance limit). The use of supercritical carbon dioxide $\left(\mathrm{scCO}_{2}\right)$ to reduce the $\mathrm{pH}$ of the recycled aggregate does not produce secondary toxic waste and also fix the $\mathrm{CO}_{2}$ released into the atmosphere. In particular, it can be very effective if the $\mathrm{scCO}_{2}$ can neutralize the recycled aggregate in a short time. In this study, the $\mathrm{scCO}_{2}$ sparging process was developed to reduce the $\mathrm{pH}$ of recycled aggregate below 9.8 and the neutralization reaction time to less than 3 hours. In experiment, the cement mortar cubes (mixed the cement and sand; 1 x 1 x $1 \mathrm{~cm}$ in size) were used for the consistency of each recycled aggregate samples' surface and composition. The $\mathrm{scCO}_{2}$ was stored at 110 bar and $50{ }^{\circ} \mathrm{C}$ in a $75 \mathrm{~L}$ stainless steel tank. The $\mathrm{scCO}_{2}$ produced from the tank was sparged into the bottom inlet of the high pressure cell $(100 \mathrm{~mL}$ of capacity) containing $30 \mathrm{~g}$ of mortar and $60 \mathrm{~mL}$ of distilled water at a pressure of 90 bar $(\Delta \mathrm{p}: 10$ bar) for 1 hour. During the $\mathrm{scCO}_{2}$ sparging, the inside of the cell was maintained at 80 bar and $50{ }^{\circ} \mathrm{C}$ by constantly discharging gaseous $\mathrm{CO}_{2}$ at a pressure of 10 bar through the outlet on the top of the cell. The microbubbles formed in $\mathrm{scCO}_{2}$ sparging can penetrate into the microcracks and pores of the mortar to promote the dissolution of $\mathrm{Ca}(\mathrm{OH})_{2}$ which causes the high $\mathrm{pH}$ of the mortar. After 1 hour of $\mathrm{scCO}_{2}$ sparging, the cell was stabilized at 80 bar and $50{ }^{\circ} \mathrm{C}$ for 2 hours by reacting supersaturated calcium solution with dissolved $\mathrm{CO}_{2}$ to induce the precipitation of calcium carbonate $\left(\mathrm{CaCO}_{3}\right)$. The $\mathrm{scCO}_{2}$-mortar-water dissolution reaction without $\mathrm{scCO}_{2}$ sparging process was also performed for 3 hours at 80 bar and $50{ }^{\circ} \mathrm{C}$. After the dissolution reaction, the amounts of $\mathrm{Ca}(\mathrm{OH})_{2}$ dissolution in solution and $\mathrm{CaCO}_{3}$ precipitation on mortar surface without $\mathrm{scCO}_{2}$ sparging process were compared with those with $\mathrm{scCO}_{2}$ sparging process. When the $\mathrm{scCO}_{2}$ sparging process was applied, the $\mathrm{Ca}(\mathrm{OH})_{2}$ dissolution in water increased more than 1.7 times and the precipitation of $\mathrm{CaCO}_{3}$ also increased more than 1.4 times, compared with results of only $\mathrm{scCO}_{2}$ dissolution reaction (without $\mathrm{scCO}_{2}$ sparging process). Results suggested that the $\mathrm{scCO}_{2}$ sparging process can maintain the $\mathrm{pH}$ of the mortar below 9.8. Because the $\mathrm{Ca}(\mathrm{OH})_{2}$ content in cement mortar is lower than that in recycled aggregate, the neutralization effect of the $\mathrm{scCO}_{2}$ sparging process on the recycled aggregate is higher than on the cement mortar, suggesting that the $\mathrm{scCO}_{2}$ sparging process for only 3 hours has very high capacity to maintain the $\mathrm{pH}$ of recycled aggregate below 9.8 . 